\title{
Short communication: Composition of coproduct streams from dairy processing: Acid whey and milk permeate
}

\author{
Pedro Menchik, Tristan Zuber, Anika Zuber, and Carmen I. Moraru* \\ Department of Food Science, Cornell University, Ithaca, NY 14853
}

\section{ABSTRACT}

This article provides composition information for 3 abundantly available but little characterized dairy coproduct streams: acid whey from Greek yogurt (GAW), acid whey from cottage cheese (CAW), and milk permeate (MP). Three replicate samples obtained on different dates from several dairy processors were analyzed. The main component in all streams was lactose, with up to 3.5, 2.1, and $11.9 \%$ in GAW, CAW, and MP, respectively. Crude protein content ranged from 1.71 to 3.71 $\mathrm{mg} / \mathrm{g}$ in GAW, 1.65 to $5.05 \mathrm{mg} / \mathrm{g}$ in CAW, and 3.2 to $4.35 \mathrm{mg} / \mathrm{g}$ in $\mathrm{MP}$, and $\mathrm{pH}$ ranged from 4.21 to 4.48 , 4.35 to 4.51 , and 5.4 to 6.37 , respectively. Chemical oxygen demand varied from 52,400 to $62,400 \mathrm{mg} / \mathrm{L}$ for GAW, 31,900 to $40,000 \mathrm{mg} / \mathrm{L}$ for CAW, and 127000 to $142,000 \mathrm{mg} / \mathrm{L}$ for MP; biochemical oxygen demand ranged from 45,800 to $50,500 \mathrm{mg} / \mathrm{L}$ (GAW), 32,700 to $40,000 \mathrm{mg} / \mathrm{L}$ (CAW), and 110,000 to $182,000 \mathrm{mg} / \mathrm{L}$ (MP). The GAW had the lowest $\mathrm{pH}(4.21-4.48)$ and highest mineral content of all streams. These data will assist processors and researchers in developing valueadded uses of these dairy coproducts.

Key words: Greek yogurt acid whey, cottage cheese acid whey, milk ultrafiltration permeate, dairy coproducts

\section{Short Communication}

The last decade was defined by a very high interest in high-protein foods, which resulted in the surge of high-protein dairy products such as Greek-style yogurt (GSY) or beverages fortified with proteins obtained by membrane fractionation of milk or cheese whey. During the manufacture of such products, a significant portion of the water and water-soluble components in milk such as lactose and minerals are being removed as either whey or permeate. With growing volumes of the highprotein products, high volumes of these streams are

Received November 6, 2018.

Accepted January 23, 2019.

*Corresponding author: cim24@cornell.edu also produced. In the past, these streams were deemed as byproducts, and often times they were disposed as waste. However, such streams can present a huge environmental concern due to their high content of OM, which can lead to algal bloom and depletion of oxygen in water streams (Arla Foods Ingredients, 2017; Erickson, 2017). For example, the average biochemical oxygen demand (BOD) for some whey streams was reported to be around $40,000 \mathrm{mg} / \mathrm{L}$ (Jelen, 2011), which is about 30 times higher than the effluent limit prescribed for cultured dairy products and 130 times higher than the effluent limit for cheese products (CFR, 2017). Therefore, pressure is mounting on the industry to fully use all milk components. To reflect the change of attitude toward these streams, in recent years the term coproducts started being used instead of byproducts.

Acid whey and permeate from membrane fractionation represent, by volume, the most significant coproducts currently generated by the US dairy industry. Acid whey is generated from products such as cottage cheese or GSY, in which casein coagulation is driven by $\mathrm{pH}$ reduction by either lactic fermentation or direct acidification. Similar to the sweet whey obtained from cheese making, acid whey consists mostly of water, with lactose as the main solid, but has a much lower protein content, and higher acidity and mineral content than sweet whey. This results in significant differences in sensory, nutritional, and technological properties, as well as different strategies for its usage and processing for the 2 types of whey (Jelen, 2011). In particular, acid whey from Greek-style yogurt (GAW) has a lower protein content than the other types of whey, due to the depletion of whey proteins caused by the extended heat treatment used in yogurt making (Gyawali and Ibrahim, 2016).

Large volumes of GSY are currently produced, both in the United States and abroad. In 2004, GSY accounted for less than $2 \%$ of all yogurt types produced in the United States, but in 2015 this number skyrocketed to almost $40 \%$, amounting to an impressive 771,000 $\mathrm{t}$ of Greek yogurt (Erickson, 2017). The straining or centrifugation associated with the manufacture of GSY results in high quantities of GAW, since on average 2 
$\mathrm{kg}$ of whey are produced for every $1 \mathrm{~kg}$ of Greek yogurt (Erickson, 2017). In New York State alone, which is currently the largest yogurt-producing state in the United States, about 300,000 t of GAW were produced in 2012 (DEC, 2012). To date, GAW use has been limited to low added-value applications, and most processors have yet to find an economically feasible way to incorporate it into higher-value products. A few solutions have been proposed, so far with mild success (Arla Foods Ingredients, 2017; Erickson, 2017). Current applications of GAW include irrigation, feed for livestock, and energy generation in wastewater bioreactors (DEC, 2012).

Similar to acid whey, the permeate obtained from the ultrafiltration of skim milk is also depleted from proteins, but contains the other soluble components of milk. The industry is actively seeking ways to find value-added uses for coproducts such as acid whey and permeate, which will help increase the value of milk and improve the sustainability of the dairy industry. These coproducts still contain important components such as lactose, minerals, AA, and even small amounts of protein that could be used in added-value products such as fermented goods, sports beverages, snacks, and baby food formula, to name a few (Arla Foods Ingredients, 2017).

One of the challenges in developing such applications is the fact that information about the composition of these streams is not readily available. In this context, the main objective of this paper is to provide a detailed composition of some less well-characterized dairy coproduct streams, including acid whey from GSY and cottage cheese, and milk permeate. This information will help dairy processors and researchers make more informed decisions regarding the valorization and potential applications of these coproducts in the future.

Four dairy coproducts were collected during September 2015 (1 replicate) and February 2016 (2 replicates) from 3 companies located in New York State: (1) acid whey from Greek-style yogurt from company A; (2) acid whey from Greek-style yogurt from company B; (3) acid whey from cottage cheese from company B (CAW); and (4) milk UF permeate from company C (MP). All samples were stored refrigerated from collection until the time of analyses. Details about sample handling are provided in Table 1. Each of the individual samples was analyzed in triplicate.

Table 1 summarizes the assays performed for the first batch of coproducts collected, the laboratories responsible, and the methodologies used. For the second batch of samples, the number of analyses was reduced to those deemed most critical, which are indicated in bold face font in Table 1. For the second batch of samples, the BOD and chemical oxygen demand (COD) assays were performed by a different laboratory, for logistical reasons.

Because some of the protein assays gave results that were below the limit of detection, total CP (in $\mathrm{mg} / \mathrm{g}$ ) was calculated as (total nitrogen $/ 1,000) \times 6.38$. The amount of individual protein fractions, such as $\alpha$-LA and $\beta-\mathrm{LG}$, were then calculated by multiplying their reported percentages by the total $\mathrm{CP}$ obtained as mentioned above.

The methodologies used for determining the nitrogen fractions (nitrates, ammonia, urea) are described in the compendium of analytical procedures by Dairy One (Dairy One, 2015). The various protein fractions were analyzed by capillary gel electrophoresis by L. Metzger's laboratory at South Dakota State University, using the procedure described below, as provided directly by South Dakota State University.

A $10-\mu \mathrm{L}$ sample was mixed with $85 \mu \mathrm{L}$ of sample buffer (Beckman-Coulter, Fullerton, CA) and $5 \mu \mathrm{L}$ of $\beta$-mercaptoethanol in a micro-vial. Each micro-vial was capped tightly, mixed thoroughly, and then heated in a water bath at $90^{\circ} \mathrm{C}$ for $10 \mathrm{~min}$, then cooled to room temperature. The capillary gel electrophoresis was carried out using a Beckman P/ACE MDQ capillary electrophoresis system (Beckman-Coulter) equipped with a UV detector set at $214 \mathrm{~nm}$. The separation was performed using a $50 \mu \mathrm{m}$ bare fused silica capillary (20.2 $\mathrm{cm}$ effective length from the inlet to the detection window). All solutions and reagents were obtained as a part of the ProteomeLab SDS-MW Analysis Kit (Beckman-Coulter) designed for the separation of protein-SDS complexes using a replaceable gel matrix. The gel is formulated to provide an effective sieving range of approximately 10 to $225 \mathrm{kDa}$. A capillary preconditioning method was run every 3 samples. This consisted of a basic rinse $(0.1 \mathrm{~N} \mathrm{NaOH}, 5 \min , 345 \mathrm{kPa})$, followed by an acidic rinse $(0.1 \mathrm{~N} \mathrm{HCl}, 2 \mathrm{~min}, 345 \mathrm{kPa})$, a water rinse (HPLC grade water, $2 \min , 345 \mathrm{kPa}$ ), and finally a SDS gel rinse (SDS gel fill, $10 \mathrm{~min}, 275 \mathrm{kPa}$ ). After the preconditioning steps the sample was electrokinetically introduced at $5 \mathrm{kV}$ for $20 \mathrm{~s}$. The separation was performed at a constant voltage of $15 \mathrm{kV}$ (at a temperature of $25^{\circ} \mathrm{C}$ and a pressure of 20 bar) with reverse polarity in the SDS-molecular weight gel buffer. Actual current values were recorded to determine the efficiency of each electrophoretic run. Molecular weight standards (Proteome Lab and Beckman-Coulter) and available pure milk protein fractions (Sigma, St. Louis, MO) were also separated using the method as described above to determine migration times. The peaks in the capillary electropherogram were identified by comparing the migration time of molecular weight standards and pure standard samples as well as by comparison 


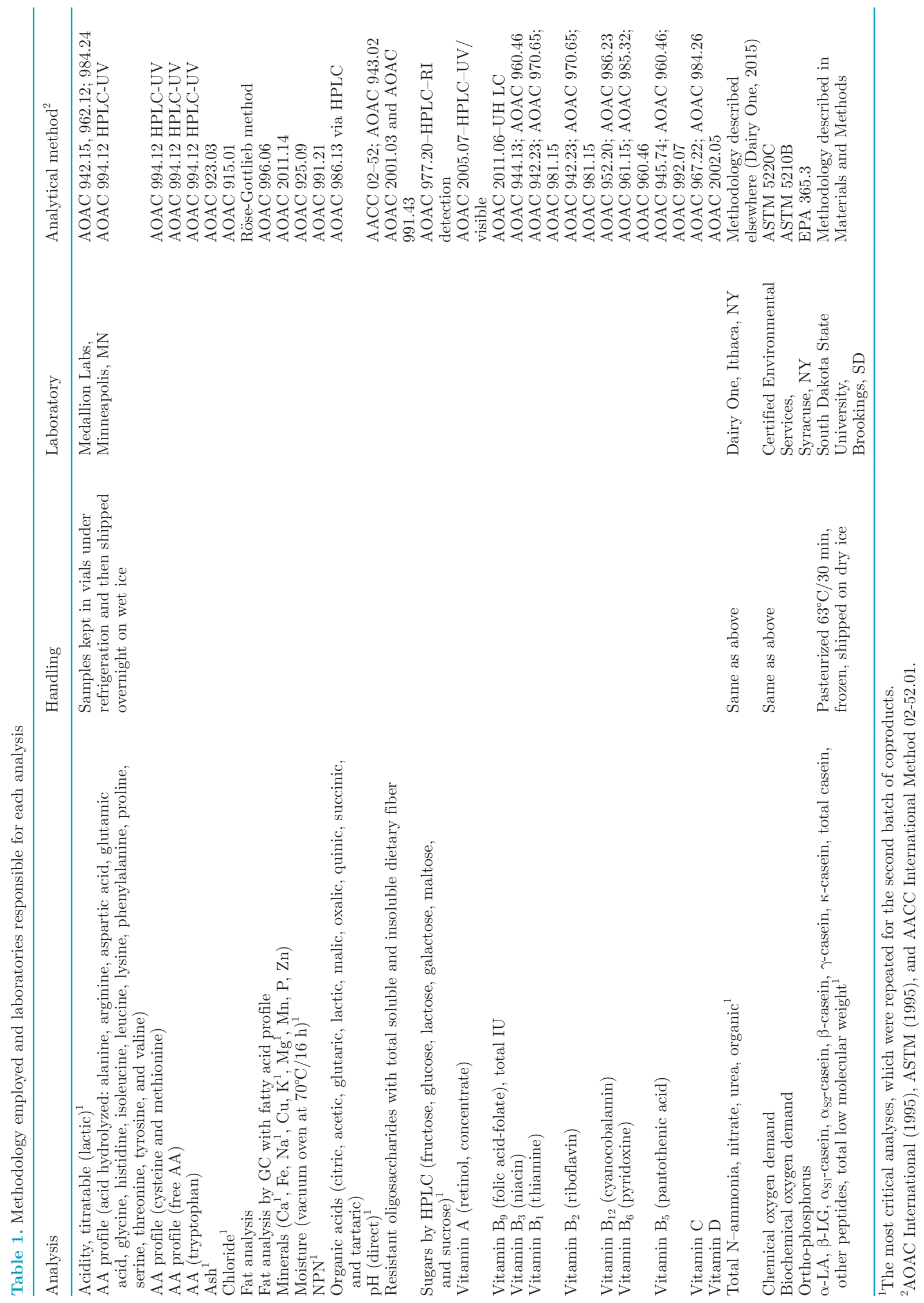


Table 2. Composition data for the first batch of coproducts [replicate (Rep.) 1] ${ }^{1}$

\begin{tabular}{|c|c|c|c|c|c|}
\hline \multirow[b]{2}{*}{ Analysis } & \multirow[b]{2}{*}{ Units $^{2}$} & \multirow{2}{*}{$\frac{\text { Company A }}{\text { GAW }}$} & \multicolumn{2}{|c|}{ Company B } & \multirow{2}{*}{$\frac{\text { Company C }}{\mathrm{MP}}$} \\
\hline & & & GAW & CAW & \\
\hline TS & $\% \mathrm{wt} / \mathrm{wt}$ & 6.0 & 6.0 & 3.7 & 13.4 \\
\hline Total N (TN) & $\mathrm{mg} / \mathrm{kg}$ & 581 & 390 & 259 & 502 \\
\hline Ammonia-N & & 83 & 79 & 58 & $<5$ \\
\hline Urea-N & & ND & $<5$ & $<5$ & 227 \\
\hline Nitrate-N & & ND & ND & ND & ND \\
\hline NPN & $\%$ of TN & 0.17 & 0.16 & 0.13 & 0.35 \\
\hline Total protein (calculated) & $\mathrm{mg} / \mathrm{g}$ & 3.71 & 2.49 & 1.65 & 3.2 \\
\hline$\alpha-\mathrm{LA}$ & & 0.50 & 0.47 & 0.22 & 0.52 \\
\hline$\beta-\mathrm{LG}$ & & 0.11 & 0.13 & 0.83 & 1.18 \\
\hline Total casein & & 0.00 & 0.02 & 0.07 & 0.00 \\
\hline$\alpha_{\mathrm{S} 1}$-Casein & & 0.00 & 0.00 & 0.00 & 0.00 \\
\hline$\alpha_{\mathrm{S}^{-}}$Casein & & 0.00 & 0.00 & 0.00 & 0.00 \\
\hline$\beta$-Casein & & 0.00 & 0.00 & 0.00 & 0.00 \\
\hline$\gamma$-Casein & & 0.00 & 0.00 & 0.00 & 0.00 \\
\hline$\kappa$-Casein & & 0.00 & 0.00 & 0.00 & 0.00 \\
\hline Other peptides & & 0.00 & 0.00 & 0.08 & 0.08 \\
\hline Total low molecular weight & & 3.09 & 1.87 & 0.45 & 1.42 \\
\hline \multicolumn{6}{|l|}{ AA } \\
\hline Hydroxyproline & $\%$ & ND & ND & ND & ND \\
\hline Aspartic acid & & 0.011 & 0.018 & 0.034 & 0.012 \\
\hline Threonine & & 0.006 & 0.008 & 0.015 & 0.004 \\
\hline Serine & & 0.006 & 0.008 & 0.013 & 0.004 \\
\hline Glutamic acid & & 0.022 & 0.03 & 0.055 & 0.021 \\
\hline Proline & & 0.008 & 0.011 & 0.017 & 0.003 \\
\hline Glycine & & 0.002 & 0.004 & 0.005 & 0.005 \\
\hline Alanine & & 0.005 & 0.006 & 0.015 & 0.005 \\
\hline Valine & & 0.005 & 0.008 & 0.016 & 0.003 \\
\hline Isoleucine & & 0.006 & 0.009 & 0.017 & 0.004 \\
\hline Leucine & & 0.009 & 0.015 & 0.036 & 0.007 \\
\hline Tyrosine & & 0.002 & 0.005 & 0.011 & 0.002 \\
\hline Phenylalanine & & 0.004 & 0.007 & 0.012 & 0.002 \\
\hline Lysine & & 0.009 & 0.015 & 0.032 & 0.008 \\
\hline Histidine & & 0.004 & 0.005 & 0.007 & 0.002 \\
\hline Arginine & & 0.003 & 0.005 & 0.009 & 0.002 \\
\hline Total hydrolyzed AA & & 0.102 & 0.154 & 0.294 & 0.084 \\
\hline Cysteine & & 0.002 & 0.003 & 0.008 & 0.003 \\
\hline Methionine & & 0.001 & 0.002 & 0.006 & 0.001 \\
\hline Taurine & & $\mathrm{M} / \mathrm{I}$ & $\mathrm{M} / \mathrm{I}$ & $\mathrm{M} / \mathrm{I}$ & 0.003 \\
\hline Asparagine & & $<\mathrm{LOQ}$ & $<\mathrm{LOQ}$ & $<\mathrm{LOQ}$ & $<\mathrm{LOQ}$ \\
\hline Glutamine & & $<\mathrm{LOQ}$ & ND & $<\mathrm{LOQ}$ & ND \\
\hline Cysteine & & ND & ND & $<\mathrm{LOQ}$ & ND \\
\hline Citrulline & & $\mathrm{ND}$ & ND & 0.001 & $<\mathrm{LOQ}$ \\
\hline Gamma-aminobutyric acid & & 0.003 & 0.004 & 0.007 & $<\mathrm{LOQ}$ \\
\hline Ethanolamine & & 0.001 & 0.001 & 0.001 & 0.007 \\
\hline Ornithine & & $<\mathrm{LOQ}$ & ND & 0.001 & 0.001 \\
\hline Total free AA & & 0.022 & 0.013 & 0.025 & 0.0035 \\
\hline Tryptophan & & $<0.01$ & $<0.01$ & $<0.01$ & $<0.01$ \\
\hline Ash & $\% \mathrm{wt} / \mathrm{wt}$ & 0.64 & 0.75 & 0.42 & 1.13 \\
\hline Calcium & $\mathrm{mg} / 100 \mathrm{~g}$ & 121 & 120 & 69.9 & 96.3 \\
\hline Iron & & $<1.00$ & $<1.00$ & $<1.00$ & $<1.00$ \\
\hline Sodium & & 37.9 & 38.7 & 23.1 & 80.6 \\
\hline Phosphorus & & 66.8 & 66.5 & 46.3 & 99.9 \\
\hline Copper & & $<1.00$ & $<1.00$ & $<1.00$ & $<1.00$ \\
\hline Potassium & & 164 & 169 & 95.2 & 360 \\
\hline Magnesium & & 10.6 & 10.4 & 6.78 & 16.3 \\
\hline Manganese & & $<1.00$ & $<1.00$ & $<1.00$ & $<1.00$ \\
\hline Zinc & & $<1.00$ & $<1.00$ & $<1.00$ & $<1.00$ \\
\hline Total chloride & $\%$ & 0.078 & 0.094 & $<0.06$ & 0.207 \\
\hline Ortho-phosphorus & $\mathrm{mg} / \mathrm{L}$ & 558 & 530 & 391 & 712 \\
\hline Total sugar (including galactose) & $\%$ & 3.92 & 4.02 & 1.99 & 10.6 \\
\hline Lactose & & 3.33 & 3.42 & 1.99 & 10.6 \\
\hline Galactose & & 0.59 & 0.60 & $<0.1$ & $<0.1$ \\
\hline Fructose & & $<0.1$ & $<0.1$ & $<0.1$ & $<0.1$ \\
\hline Glucose & & $<0.1$ & $<0.1$ & $<0.1$ & $<0.1$ \\
\hline Sucrose & & $<0.1$ & $<0.1$ & $<0.1$ & $<0.1$ \\
\hline
\end{tabular}


Table 2 (Continued). Composition data for the first batch of coproducts [replicate (Rep.) 1] ${ }^{1}$

\begin{tabular}{|c|c|c|c|c|c|}
\hline \multirow[b]{2}{*}{ Analysis } & \multirow[b]{2}{*}{ Units $^{2}$} & \multirow{2}{*}{$\frac{\text { Company A }}{\text { GAW }}$} & \multicolumn{2}{|c|}{ Company B } & \multirow{2}{*}{$\frac{\text { Company C }}{\mathrm{MP}}$} \\
\hline & & & GAW & CAW & \\
\hline Maltose & & $<0.1$ & $<0.1$ & $<0.1$ & $<0.1$ \\
\hline Total fiber & $\%$ & 0.4 & 0.3 & 0.2 & 0.2 \\
\hline Insoluble fiber & & 0 & 0 & 0 & 0 \\
\hline Soluble fiber & & 0.4 & 0.3 & 0.2 & 0.2 \\
\hline Resistant oligosaccharides & & 0 & 0 & 0 & 0 \\
\hline Total fat, chromatography ${ }^{3}$ & $\%$ & 0 & 0.01 & 0.01 & 0 \\
\hline Saturated fat & & 0 & 0.01 & 0 & 0 \\
\hline Monounsaturated fat & & 0 & 0 & 0 & 0 \\
\hline cis-cis PUFA & & 0 & 0 & 0 & 0 \\
\hline Trans fat & & 0 & 0 & 0 & 0 \\
\hline Total fat, gravimetric & & 0 & 0 & 0 & 0.01 \\
\hline \multicolumn{6}{|l|}{ Fatty acid } \\
\hline 12:0 Lauric & & 0 & 0.001 & 0 & 0 \\
\hline 16:0 Palmitic & & 0 & 0.006 & 0 & 0 \\
\hline 18:0 Stearic & & 0 & 0.003 & 0.004 & 0 \\
\hline 18:1 Oleic & & 0 & 0.003 & 0.004 & 0 \\
\hline 18:2 Linoleic & & 0 & 0.001 & 0 & 0 \\
\hline \multicolumn{6}{|l|}{ Vitamin } \\
\hline Niacin & $\mathrm{mg} / 100 \mathrm{~g}$ & 0.11 & 0.12 & 0.11 & 0.36 \\
\hline Vitamin $\mathrm{B}_{1}$ [thiamine-HCl (US)] & & 0.1 & 0.06 & 0.06 & 0.1 \\
\hline Vitamin $B_{1}$ [thiamine (EU)] & & 0.079 & 0.074 & 0.047 & 0.079 \\
\hline Vitamin $B_{2}$ (riboflavin) & & 0.12 & 0.06 & 0.04 & 0.05 \\
\hline Vitamin $\mathrm{B}_{6}$ & & $<0.02$ & $<0.02$ & $<0.02$ & 0.04 \\
\hline Pantothenic acid & & 0.459 & 0.268 & 0.246 & 0.983 \\
\hline Vitamin $\mathrm{C}$ & & $<0.5$ & $<0.6$ & $<0.5$ & $<0.5$ \\
\hline Vitamin $\mathrm{B}_{12}$ & $\mu \mathrm{g} / 100 \mathrm{~g}$ & $<0.10$ & $<0.10$ & $<0.10$ & $<0.10$ \\
\hline Folic acid & & $<5.00$ & $<5.00$ & $<5.00$ & 8.12 \\
\hline Vitamin A & $\mathrm{IU} / 100 \mathrm{~g}$ & $<50$ & $<50$ & $<50$ & $<50$ \\
\hline Vitamin D total & & $<40$ & $<40$ & $<40$ & $<40$ \\
\hline Titratable acidity (lactic acid) & $\%$ & 0.43 & 0.43 & 0.28 & 0.12 \\
\hline \multicolumn{6}{|l|}{ Organic acids } \\
\hline Oxalic acid & & $<0.01$ & $<0.01$ & $<0.01$ & $<0.01$ \\
\hline Citric acid & & 0.18 & 0.17 & 0.09 & 0.4 \\
\hline Tartaric acid & & $<0.01$ & $<0.01$ & $<0.01$ & $<0.01$ \\
\hline Malic acid & & $<0.01$ & $<0.01$ & $<0.01$ & $<0.01$ \\
\hline Quinic acid & & $<0.01$ & $<0.01$ & $<0.01$ & $<0.01$ \\
\hline Succinic acid & & $<0.01$ & $<0.01$ & $<0.01$ & $<0.01$ \\
\hline Lactic acid & & 0.65 & 0.64 & 0.37 & $<0.01$ \\
\hline Glutaric acid & & 0.06 & 0.06 & 0.04 & 0.14 \\
\hline Acetic acid & & $<0.01$ & $<0.01$ & $<0.01$ & $<0.01$ \\
\hline Fumaric acid & & $<0.01$ & $<0.01$ & $<0.01$ & $<0.01$ \\
\hline $\mathrm{pH}$ & & 4.4 & 4.4 & 4.41 & 6.37 \\
\hline Chemical oxygen demand & $\mathrm{mg} / \mathrm{L}$ & 62.200 & 64.400 & 40,000 & 142.000 \\
\hline Biochemical oxygen demand & & $>22,000$ & $>7,300$ & $>7,300$ & $>7,300$ \\
\hline
\end{tabular}

${ }^{1} \mathrm{GAW}=$ acid whey from Greek-style yogurt; CAW = acid whey from cottage cheese; $\mathrm{MP}=$ milk UF permeate; $\mathrm{ND}=$ not detected; $\mathrm{M} / \mathrm{I}=$ matrix interference; $\mathrm{LOQ}=$ limit of quantification.

${ }^{2}$ Units as reported by the analytical laboratories.

${ }^{3}$ Fatty acids not found in any of the samples are not shown in the table.

to results reported by other researchers (Creamer and Richardson, 1984; Miralles et al., 2000; Anema, 2009). The area of each identified peak was calculated from the electropherogram using a valley-to-valley approach, as described in literature (Miralles et al., 2000). The area of the each identified individual casein fraction $\left(\alpha_{\mathrm{S1}^{-}} \mathrm{CN}, \alpha_{\mathrm{S}^{-}} \mathrm{CN}, \beta-\mathrm{CN}, \kappa-\mathrm{CN}\right.$, and $\left.\gamma-\mathrm{CN}\right)$, serum protein fraction $(\alpha-\mathrm{LA}, \beta-\mathrm{LG})$, peptides (peaks between 10 and $20 \mathrm{kDa}$ ), and NPN fraction (all positive peaks below $10 \mathrm{kDa}$ ) was calculated as a percentage of total area (positive peaks).
All analyses were performed in triplicate. Data were analyzed using Microsoft Excel (2013, Microsoft Corp., Redmond, WA). Statistical differences among observed means were determined using an unpaired $t$-test with a significance level $\alpha=0.05$.

The complete results for the analyses are presented in Tables 2 and 3. All products analyzed consisted mostly of water, with a TS content of 6 to $6.2 \%$ for GAW, 3.3 to $3.7 \%$ for CAW, and 13.4 to $15.4 \%$ for MP. The main solid was lactose, for all samples: 3.3 to $3.5 \%$, 1.9 to $2.1 \%$, and 10.6 to $11.9 \%$ for GAW, CAW, and 
MP, respectively. Ash, galactose, lactic acid, and citric acid were some of the other major components for all products. The $\mathrm{pH}$ ranges were 4.21 to $4.48,4.35$ to 4.41 , and 5.4 to 6.37 for GAW, CAW, and MP, respectively. The MP is not a fermented product, hence its $\mathrm{pH}$ was around 6.3, similar to sweet whey (Huma al., 2015).

Crude protein ranged from 1.71 to $3.71 \mathrm{mg} / \mathrm{g}$ for GAW (both processors), 1.65 to $5.05 \mathrm{mg} / \mathrm{g}$ for CAW, and 3.2 to $4.35 \mathrm{mg} / \mathrm{g}$ for MP. The concentration of $\alpha-\mathrm{LA}$ was found to be very low in GAW, and it ranged from 0.17 to $0.77 \mathrm{mg} / \mathrm{L}$. Interestingly, this concentration was not found to be statistically different from those of CAW and MP, and neither were the CP contents $(P>0.05)$. By comparison, the protein content in sweet whey usually ranges from 6 to $10 \mathrm{mg} / \mathrm{g}$ (Jelen, 2011).
Besides being very small, the concentration of $\alpha$-LA in all streams showed high variability $(\mathrm{CV}=99 \%)$, which is also true for the total amount of $\mathrm{CP}(\mathrm{CV}=$ $29 \%$ ). Most of the CP analyzed was represented by low molecular weight in acid whey, which likely corresponds to the water-soluble products of proteolysis that formed during yogurt fermentation (Sfakianakis and Tzia, 2014).

The major minerals found in GAW were K (157 to $169 \mathrm{mg} / 100 \mathrm{~g}), \mathrm{Ca}(120 \mathrm{mg} / 100 \mathrm{~g}$ to $128 \mathrm{mg} / 100 \mathrm{~g})$, and $\mathrm{P}$ (66.5 to $69.2 \mathrm{mg} / 100 \mathrm{~g}$ ). The respective amounts found in CAW and MP were of the same order of magnitude, but GAW had clearly the highest concentration of $\mathrm{Ca}$ of all streams. Sweet whey, by comparison, is reported to have less than half of the Ca content present

Table 3. Composition data for the second batch of coproducts [replicates (Rep.) 2 and 3] $]^{1}$

\begin{tabular}{|c|c|c|c|c|c|c|c|c|c|}
\hline \multirow[b]{3}{*}{ Analysis } & \multirow[b]{3}{*}{ Unit $^{2}$} & \multirow{2}{*}{\multicolumn{2}{|c|}{$\begin{array}{c}\text { Company A } \\
\text { GAW }\end{array}$}} & \multicolumn{4}{|c|}{ Company B } & \multirow{2}{*}{\multicolumn{2}{|c|}{$\frac{\text { Company } \mathrm{C}}{\mathrm{MP}}$}} \\
\hline & & & & \multicolumn{2}{|c|}{ GAW } & \multicolumn{2}{|c|}{ CAW } & & \\
\hline & & Rep. 2 & Rep. 3 & Rep. 2 & Rep. 3 & Rep. 2 & Rep. 3 & Rep. 2 & Rep. 3 \\
\hline $\mathrm{TS}$ & $\% \mathrm{wt} / \mathrm{wt}$ & 6.2 & 6.1 & 6.0 & 6.1 & 3.6 & 3.3 & 14.8 & 15.4 \\
\hline Total N & $\mathrm{mg} / \mathrm{kg}$ & 371 & 268 & 431 & 489 & 791 & 552 & 682 & 584 \\
\hline Ammonia-N & & 79 & 79 & 87 & 64 & 55 & 57 & $<5$ & $<5$ \\
\hline Urea-N & & $<5$ & $<5$ & $<5$ & $<5$ & $<5$ & $<5$ & 251 & 224 \\
\hline Nitrate-N & & $\mathrm{ND}^{3}$ & ND & ND & ND & ND & ND & ND & ND \\
\hline Total protein & $\mathrm{mg} / \mathrm{g}$ & 2.37 & 1.71 & 2.75 & 3.12 & 5.05 & 3.52 & 4.35 & 3.73 \\
\hline$\alpha-\mathrm{LA}$ & & 0.25 & 0.17 & 0.77 & 0.63 & 0.71 & 0.39 & 1.62 & 1.57 \\
\hline$\beta-\mathrm{LG}$ & & 0.00 & 0.00 & 0.20 & 0.16 & 2.11 & 1.53 & 0.00 & 0.00 \\
\hline Total casein & & 0.00 & 0.00 & 0.00 & 0.00 & 0.00 & 0.00 & 0.00 & 0.00 \\
\hline$\alpha_{\mathrm{S} 1}-$ Casein & & 0.00 & 0.00 & 0.00 & 0.00 & 0.00 & 0.00 & 0.00 & 0.00 \\
\hline$\alpha_{\mathrm{S} 2}-$ Casein & & 0.00 & 0.00 & 0.00 & 0.00 & 0.00 & 0.00 & 0.00 & 0.00 \\
\hline$\beta$-Casein & & 0.00 & 0.00 & 0.00 & 0.00 & 0.00 & 0.00 & 0.00 & 0.00 \\
\hline$\gamma$-Casein & & 0.00 & 0.00 & 0.00 & 0.00 & 0.00 & 0.00 & 0.00 & 0.00 \\
\hline$\kappa$-Casein & & 0.00 & 0.00 & 0.00 & 0.00 & 0.00 & 0.00 & 0.00 & 0.00 \\
\hline Other peptides & & 0.00 & 0.00 & 0.25 & 0.22 & 1.02 & 0.57 & 0.00 & 0.00 \\
\hline Total low molecular weight & & 2.11 & 1.54 & 1.53 & 2.10 & 1.20 & 1.03 & 2.73 & 2.15 \\
\hline Ash & $\%$ & 0.67 & 0.71 & 0.67 & 0.69 & 0.41 & 0.33 & 1.20 & 1.25 \\
\hline Calcium & $\mathrm{mg} / 100 \mathrm{~g}$ & 122 & 128 & 122 & 122 & 68.3 & 70.7 & 102 & 106 \\
\hline Sodium & & 37.6 & 41.9 & 38.5 & 39.3 & 21.6 & 22.5 & 85.8 & 88.6 \\
\hline Phosphorus & & 68.2 & 69.2 & 69 & 68.5 & 48.1 & 48.9 & 108 & 113 \\
\hline Potassium & & 162 & 158 & 157 & 156 & 90.8 & 93.3 & 364 & 381 \\
\hline Magnesium & & 11 & 10.5 & 10.5 & 10.4 & 6.56 & 6.67 & 17.6 & 18.2 \\
\hline Total chloride & & 0.08 & 0.09 & 0.11 & 0.09 & 0.06 & 0.06 & 0.22 & 0.25 \\
\hline Total sugar & & 4.11 & 3.98 & 3.98 & 3.97 & 2.2 & 2.28 & 11.8 & 12.2 \\
\hline Lactose & & 3.5 & 3.33 & 3.39 & 3.41 & 2.06 & 2.13 & 11.5 & 11.9 \\
\hline Galactose & $\%$ & 0.61 & 0.65 & 0.59 & 0.56 & 0.14 & 0.15 & 0.13 & 0.16 \\
\hline Fructose & & $<0.1$ & $<0.1$ & $<0.1$ & $<0.1$ & $<0.1$ & $<0.1$ & $<0.1$ & $<0.1$ \\
\hline Glucose & & $<0.1$ & $<0.1$ & $<0.1$ & $<0.1$ & $<0.1$ & $<0.1$ & 0.151 & 0.16 \\
\hline Sucrose & & $<0.1$ & $<0.1$ & $<0.1$ & $<0.1$ & $<0.1$ & $<0.1$ & $<0.1$ & $<0.1$ \\
\hline Maltose & & $<0.1$ & $<0.1$ & $<0.1$ & $<0.1$ & $<0.1$ & $<0.1$ & $<0.1$ & $<0.1$ \\
\hline Titratable acidity $^{4}$ & $\%$ & 0.48 & 0.53 & 0.45 & 0.42 & 0.30 & 0.31 & 0.21 & 0.31 \\
\hline $\mathrm{pH}$ & & 4.21 & 4.22 & 4.35 & 4.48 & 4.37 & 4.35 & 5.88 & 5.4 \\
\hline Chemical oxygen demand & $\mathrm{mg} / \mathrm{L}$ & 56,100 & 53,700 & 52,400 & 54,900 & 31,900 & 38,700 & 127,000 & 133,000 \\
\hline Biochemical oxygen demand & & 45,800 & 45,800 & 50,500 & 46,100 & 32,700 & 40,000 & 182,000 & 110,000 \\
\hline
\end{tabular}

${ }^{1} \mathrm{GAW}=$ acid whey from Greek-style yogurt; CAW = acid whey from cottage cheese; MP = milk UF permeate

${ }^{2}$ Units as reported by the analytical laboratories.

${ }^{3} \mathrm{ND}=$ not detected.

${ }^{4}$ Expressed as lactic acid. 
in GAW (Jelen, 2011). Other minerals of importance include $\mathrm{Na}$ and $\mathrm{Mg}$, with $\mathrm{Na}$ concentration being the highest in MP, which explains its potential use as a salt replacer in some applications.

Interestingly, all streams also presented small quantities of fiber, which may be galacto-oligosaccharides formed during the manufacturing process, because acids can act as catalysts for the polymerization of lactose (Tremaine et al., 2014). The main vitamins found in the coproducts were pantothenic acid, niacin, thiamine, and riboflavin, the latter being responsible for giving whey the characteristic bright yellowish-green color.

The COD varied from 52,400 to $64,400 \mathrm{mg} / \mathrm{L}$ for GAW, 31,900 to $40,000 \mathrm{mg} / \mathrm{L}$ for CAW, and 127,000 to $142,000 \mathrm{mg} / \mathrm{L}$ for MP, whereas for BOD the ranges were 45,800 to $50,500,32,700$ to 40,000 , and 110,000 to $182,000 \mathrm{mg} / \mathrm{L}$, respectively. The BOD ranges for GAW are almost 40 times the effluent limitation guidelines for cultured dairy products (CFR, 2017).

Overall, the dairy coproducts characterized in this study contained some milk solids that could potentially be extracted, purified, and used in certain applications, particularly lactose, minerals, and some low-molecularweight nitrogen compounds. The composition data provided will assist dairy processors and product developers make better-informed decisions about how to best use these coproducts, with nutritional benefits for consumers, economic benefits for industry, and environmental benefits at the societal level.

\section{ACKNOWLEDGMENTS}

The present study was funded by the New York State Department of Environmental Conservation. Funding for author P. Menchik was provided by Coordenação de Aperfeiçoamento de Pessoal de Nível Superior (CAPES), Brazil. The authors also acknowledge the assistance provided by Kyle Kriner from Cornell University.

\section{REFERENCES}

Anema, S. G. 2009. The use of "lab-on-a-chip" microfluidic SDS electrophoresis technology for the separation and quantification of milk proteins. Int. Dairy J. 19:198-204. https://doi.org/10.1016/j .idairyj.2008.11.001.

AOAC International. 1995. Official Methods of Analysis of AOAC International, 18th ed.; AOAC International, Arlington, VA.

Arla Foods Ingredients. 2017. Acid whey isn't waste it's a goldmine, says Arla Foods Ingredients. Accessed Jul. 5, 2017. https://www .arlafoodsingredients.com/the-whey-and-protein-blog/archive/ issue-51/acid-whey-isnt-waste-its-a-goldmine-says-arla-foods -ingredients/.

ASTM. 1995. Standard Test Method for Total Oxygen Demand in Water 1. ASTM International, West Conshohocken, PA.

CFR. 2017. 40CFRI, Subchapter N: Effluent Guidelines and Standards, Part 405-Dairy products processing point source category. Accessed Jul. 6, 2017. https://www.ecfr.gov/cgi-bin/text-idx?SID $=9 \mathrm{~b} 2 \mathrm{ad} 535 \mathrm{~d} 533 \mathrm{c} 8 \mathrm{e} 67 \mathrm{ed} 84 \mathrm{ba} 64 \mathrm{ff} 900 \mathrm{de} \& \mathrm{mc}=$ true $\&$ node $=\mathrm{pt} 40.31$ $.405 \&$ rgn $=\operatorname{div} 5 \#$ se40.31.405_130.

Creamer, L. K., and T. Richardson. 1984. Anomalous behavior of bovine alpha s1- and beta-caseins on gel electrophoresis in sodium dodecyl sulfate buffers. Arch. Biochem. Biophys. 234:476-486.

Dairy One. 2015. Analytical Procedures. Accessed Feb. 28, 2018 http://dairyone.com/wp-content/uploads/2014/02/Forage-Lab -Analytical-Procedures-Listing-Alphabetical-July-2015.pdf.

DEC. 2012. Whey Management for Agriculture-NYS Dept. of Environmental Conservation. Accessed Apr. 26, 2017. http://www.dec .ny.gov/chemical/94164.html.

EPA. 1978. Method 365.3: Phosphorous, All Forms (Colorimetric, Ascorbic Acid, Two Reagent). US Environmental Protection Agency, Washington, DC.

Erickson, B. 2017. Acid whey: Is the waste product an untapped goldmine? Chemical \& Engineering News. Accessed Nov. 2, 2018. http: //cen.acs.org/articles/95/i6/Acid-whey-waste-product-untapped .html.

Gyawali, R., and S. A. Ibrahim. 2016. Effects of hydrocolloids and processing conditions on acid whey production with reference to Greek yogurt. Trends Food Sci. Technol. 56:61-76. https://doi .org/10.1016/j.tifs.2016.07.013.

Huma, N., I. Pasha, M. Sarwar, S. Ahmad, and F. Shah. 2015. Effect of different filtration membranes on composition of sweet and acid whey protein. Pak. J. Food Sci. 25:79-85.

Jelen, P. 2011. Utilization and Products. Whey Processing. Pages 731738 in Encyclopedia of Dairy Sciences, 2nd ed. J. F. Fuquay, ed. Academic Press, Cambridge, MA.

Miralles, B., M. Ramos, and L. Amigo. 2000. Application of capillary electrophoresis to the characterization of processed cheeses. J. Dairy Res. 67:91. https://doi.org/10.1017/S0022029999003969.

Sfakianakis, P., and C. Tzia. 2014. Conventional and innovative processing of milk for yogurt manufacture; development of texture and flavor: A review. Foods 3:176-193. https://doi.org/10.3390/ foods 3010176 .

Tremaine, A. J., E. M. Reid, C. E. Tyl, and T. C. Schoenfuss. 2014 Polymerization of lactose by twin-screw extrusion to produce indigestible oligosaccharides. Int. Dairy J. 36:74-81. https://doi.org/ 10.1016/j.idairyj.2013.12.013. 